\title{
Postnatal Development of the Vallate Papilla and Taste Buds in Rats
}

\author{
MARK A. HOSLEY AND BRUCE OAKLEY \\ Department of Biology, University of Michigan, Ann Arbor, MI 48109
}

\begin{abstract}
The postnatal maturation of the vallate papilla and its taste buds was quantitatively investigated in rats by light microscopy. Specifically, we measured postnatal increases in the size of mature vallate taste buds and the vallate papilla, increases in the thickness of the gustatory epidermis, and increases in the number of mature taste buds and taste cells per bud. Mature taste buds, defined as those having a taste pore, are rare at birth but proliferate rapidly during the first postnatal month until an average of 610 mature taste buds has accumulated by 90 days. Throughout this postnatal period, mature taste buds adjust to the developmental thickening of the epidermis by continuously increasing in length. Mature taste buds also increase in width, in part due to a threefold increase from 10 and 45 days in the number of taste cells per bud. From 10 to 21 days there is an average daily net increase of three cells per mature taste bud. The maturational increase in taste buds and cells may contribute to the functional changes in taste nerve responses known to occur over the course of several generations of taste receptor cells. The dimensions of the vallate papilla and the surface area of the gustatory epithelium increase logarithmically with age. Although mature taste buds continue to increase in number until 90 days, both taste bud density $\left(178 / \mathrm{mm}^{2}\right)$ and the number of cells per mature taste bud ( $70-75$ cells) reach ceilings by 45 days. Thus, densitydependent factors appear to control vallate taste bud maturation. The immaturity of lingual taste buds in newborn rats supports the view that odor, rather than taste, is the chemosensory signal that guides suckling in altricial rodents.
\end{abstract}

The rat possesses three types of lingual papillae which contain taste buds: the fungiform, foliate, and vallate papillae (Fish et al., 1944). Several studies have examined the structural and functional development of fungiform taste buds (Farbman, 1965; Bradley and Stern, 1967; Bradley, 1972; Mistretta, 1972; Mistretta and Bradley, 1983a,b), whereas the development of the vallate papilla and its taste buds has been less well studied. The vallate papilla in the rat embryo is first detectable at embryonic day 15 as an epidermal thickening surrounded by an elliptical ring of epidermis which penetrates into the dermis (Torrey, 1940; Mistretta, 1972). This penetrating epidermal ring splits to form the inner and outer trench walls of the papilla and is a characteristic trait of the papilla's development in several mammals (Rehmer, 1969; Bradley, 1972; Geerdink, 1973). The inner trench wall circumscribes the "centrum" of the papilla, except at the papilla's anterior margin, where the right and left trenches fail to unite. The taste buds of the vallate papilla lie primarily within the trench wall epithelium. Most vallate taste buds are bilaterally innervated by the glossopharyngeal nerve (Whiteside, 1927; Guth, 1963; Oakley, 1974).

Torrey (1940) reported that rat vallate taste buds were first observed 8-10 days after birth. In contrast, some precocial species, with a longer gestational period, develop mature taste buds during the third trimester of gestation (Bradley and Stern, 1967; Bradley et al., 1980;
Zahm and Munger, 1983). If taste were important in controlling suckling in newborn rats, one would anticipate a substantial number of mature taste buds at birth. Accordingly, we chose to examine rats throughout their neonatal life to determine when mature vallate taste buds first appeared and how rapidly they increased in numbers. Thus, the present investigation examines the postnatal development of the vallate papilla including changes in the number, size, and spatial density of its mature taste buds.

\section{MATERIALS AND METHODS}

One hundred twenty-nine male and female SpragueDawley albino rats (Rattus norvegicus) were examined. They ranged in age from embryonic day 13 through 180 days post-partum. A sample size of five to nine animals was obtained for each sacrifice age. Animals younger than 10 days were sacrificed by cervical dislocation while older animals were sacrificed with an overdose of sodium pentobarbital. The individual papillae were excised and fixed by immersion in a solution of $10 \%$ formalin, $15 \%$ sucrose, and $1 \% \mathrm{NH}_{4} \mathrm{OH}$. Following fixation, the tissue was dehydrated through a graded ethanol series to xylene and embedded in paraffin or Paraplast

Received June 11, 1985; accepted December 22, 1986.

M. Hosley's present address is Brown University Medical School, Providence, RI. 
(American Scientific Products, Detroit, MI). Serial transverse sections were stained with Heidenhain's iron-hematoxylin (Humanson, 1979). Comparison with fresh frozen sections allowed the dimensions of the vallate papilla and taste buds to be corrected for shrinkage produced by tissue processing; a correction factor of 1.27 was used. All measurements include the correction factor.

The number of mature vallate taste buds (those with a taste pore) was measured in transverse sections $10 \mu \mathrm{m}$ thick. Taste bud counts were based on the presence of the taste pore in order to have a standard index of maturity throughout the postnatal period and to avoid multiple counts of individual taste buds. A mature taste bud has a single 4-8- $\mu \mathrm{m}$-wide pore; by definition, immature taste buds do not possess pores. By counting taste bud pores in $10-\mu \mathrm{m}$ sections, the likelihood of counting a mature taste bud more than once was minimized while counts of immature taste buds were avoided. Measurements of three 10- $\mu \mathrm{m}$ transverse sections at the mid-length of the papilla provided averages for the width of the papilla's centrum, depth of the trench, and maximal thickness of the trench wall epidermis (Table 1). The length of the papilla was calculated by multiplying the number of transverse sections in which the papilla's centrum appeared by the section thickness of $10 \mu \mathrm{m}$.

Six-micron thick sections of taste buds located in the middle of the papilla were used both for intragemmal cell counts and for measurements of taste bud length and width in 3 animals each at $10,21,45$, and 90 days. Thus, in these 6- $\mu \mathrm{m}$ sections we examined 5-6 mature taste buds from each of the four papillary walls for a total of 20-24 taste buds in each of three rats at four ages.

To calculate the surface area of the epidermis lining the trench walls we assumed the trench walls of the papilla formed two hollow, concentric elliptical cylinders with no intervening gap. The trench depth equalled the cylinders' height, whereas the centrum's length and width corresponded to the major and minor axes of the inner cylinder, respectively. Thus, the total trench wall surface area was calculated according to the following equation:

Inner + outer trench wall surface area $\left(\mathrm{mm}^{2}\right)=$ $\pi \mathrm{D}(\mathrm{L}+\mathrm{W})$, where $\mathrm{D}=$ trench depth, $\mathrm{L}=$ centrum length, and $\mathrm{W}=$ centrum width $(\mathrm{mm})$. This computation is subject to the following considerations. The trench depth was measured at the papilla's mid-length, where it is maximal. Trench depth remains constant $( \pm 10 \%)$ for more than three-fourths of the papilla's length, but decreases at the anterior and posterior extremes. The posteriorly tapered papilla is not a perfect ellipse.

Statistical analysis was aided by the MIDAS statistical program at the University of Michigan computer facilities. Linear regression analysis was performed on data in which either the independent or both the independent and dependent variables underwent log transformations. ANOVA analysis of pair-wise comparisons of means determined which values differed significantly from one another. For comparisons between two selected means, the Student's t-test was also used, with $P<0.01$ as the level of acceptance. Since there were no significant sex differences in the features of the taste buds or papilla which were measured, values from males and females have been combined in the results.

\section{RESULTS}

Several developmental changes are qualitatively evident in the contrasting appearances of the vallate trench at 10 days (Fig. 1A) and 45 days (Fig. 1B). Although at both 10 and 45 days, mature taste buds span the full thickness of the epidermis, at $\mathbf{4 5}$ days the epidermis is noticeably thicker and the taste buds are considerably larger and more numerous. Taste buds become larger

TABLE 1. Morphometric measurements of postnatal vallate papilla and taste buds ${ }^{1}$

\begin{tabular}{|c|c|c|c|c|c|c|c|c|c|c|c|}
\hline & \multicolumn{11}{|c|}{ Sacrifice age (days post-partum) } \\
\hline & 0 & 3 & 10 & 15 & 21 & 33 & 45 & 60 & 90 & 120 & 180 \\
\hline Outer right trench & 0.1 & 4.8 & 33.4 & 32.4 & 57.7 & 102.2 & 99.6 & 131.0 & 151.9 & 127.2 & 138.7 \\
\hline wall taste buds & \pm 0.48 & $3 \pm 5.3$ & \pm 14.2 & \pm 3.2 & \pm 12.7 & \pm 34.4 & \pm 27.0 & \pm 39.8 & \pm 37.1 & +35.3 & \pm 24.5 \\
\hline Inner right trench & 0.0 & 3.8 & 30.4 & 40.0 & 70.7 & 102.0 & 116.1 & 143.8 & 161.4 & 141.2 & 149.7 \\
\hline wall taste buds & \pm 0.0 & \pm 4.7 & \pm 9.9 & \pm 12.6 & \pm 15.2 & \pm 26.2 & \pm 19.2 & \pm 41.9 & \pm 33.3 & \pm 35.6 & \pm 11.0 \\
\hline Inner left trench & 0.0 & 4.1 & 28.6 & 38.4 & 67.9 & 109.9 & 130.0 & 144.0 & 152.0 & 167.0 & 140.9 \\
\hline wall taste buds & \pm 0.0 & \pm 2.8 & \pm 9.8 & \pm 5.2 & \pm 16.4 & \pm 24.9 & \pm 21.8 & \pm 23.5 & \pm 20.9 & \pm 22.1 & \pm 15.2 \\
\hline Outer left trench & 0.0 & 4.2 & 31.6 & 40.4 & 70.3 & 90.0 & 114.1 & 126.8 & 146.0 & 162.2 & 143.7 \\
\hline wall taste buds & \pm 0.0 & \pm 4.9 & \pm 9.2 & \pm 5.3 & \pm 16.4 & \pm 17.8 & \pm 16.8 & \pm 24.8 & \pm 26.8 & \pm 44.1 & \pm 29.1 \\
\hline Papilla length $(\mu \mathrm{m})$ & 359 & 431 & 571 & $\overline{781}$ & 752 & 838 & 733 & 880 & 894 & & \\
\hline & \pm 85 & \pm 99 & \pm 87 & \pm 136 & \pm 82 & \pm 107 & \pm 186 & \pm 145 & \pm 153 & & \\
\hline Papilla width $(\mu \mathrm{m})$ & 257 & 296 & 429 & 440 & 513 & 670 & 571 & 664 & 713 & & \\
\hline & \pm 50 & \pm 42 & \pm 76 & \pm 90 & \pm 78 & \pm 67 & \pm 85 & \pm 82 & \pm 90 & & \\
\hline Trench depth $(\mu \mathrm{m})$ & $\begin{array}{r}244 \\
+\quad 68\end{array}$ & 193 & 375 & 417 & 452 & 518 & 692 & 776 & 603 & & \\
\hline $\begin{array}{l}\text { Trench wall surface } \\
\text { area }\left(\mathrm{mm}^{2}\right)\end{array}$ & \pm 68 & $\begin{array}{r} \pm 73 \\
0.44\end{array}$ & $\begin{array}{l} \pm 36 \\
1.24\end{array}$ & $\begin{array}{r} \pm 86 \\
1.60\end{array}$ & \pm 42 & $\begin{array}{r} \pm 88 \\
2.41\end{array}$ & $\begin{array}{r} \pm 86 \\
2.77\end{array}$ & $\begin{array}{l} \pm 76 \\
3.13\end{array}$ & $\begin{array}{r} \pm 133 \\
3.67\end{array}$ & & \\
\hline Epidermal thickness $(\mu \mathrm{m})$ & 32 & 42 & 57 & 66 & 73 & 97.6 & 102 & 101 & 102 & & \\
\hline Taste bud length $(\mu \mathrm{m})$ & \pm 7 & \pm 3 & $\begin{array}{r} \pm 4 \\
43\end{array}$ & \pm 7 & $\begin{array}{r} \pm 7 \\
83\end{array}$ & \pm 7.9 & $\begin{array}{l} \pm 6 \\
106\end{array}$ & \pm 3 & $\begin{array}{r} \pm 11 \\
102\end{array}$ & & \\
\hline & & & \pm 7 & & \pm 11 & & \pm 18 & & \pm 16 & & \\
\hline Taste bud width $(\mu \mathrm{m})$ & & & 26 & & 45 & & 59 & & 54 & & \\
\hline & & & \pm 10 & & \pm 11 & & \pm 10 & & \pm 9 & & \\
\hline Cells/taste bud & & & 22.3 & & 54.5 & & 74.0 & & 70.6 & & \\
\hline
\end{tabular}

${ }^{1}$ Entries are means \pm 1 S.D., with a sample size of 5-9. 

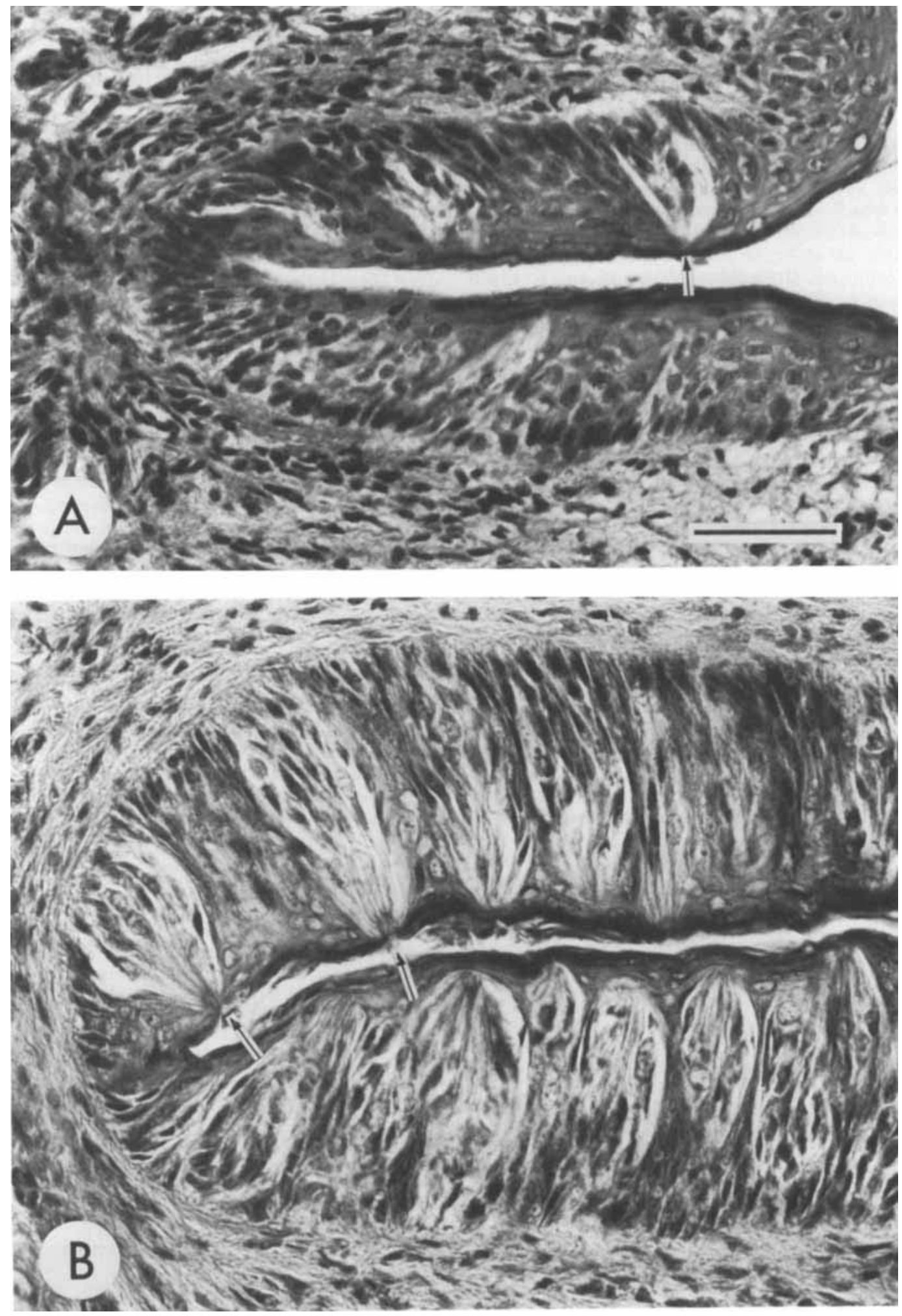

Fig. 1. Rat vallate trench wall and taste buds at age $10(\mathrm{~A})$ and 45 days (B). The scale line $=40 \mu \mathrm{m}$ for both $\mathrm{A}$ and $\mathrm{B}$. Arrows indicate the taste pore of mature taste buds. 
postnatally as a result of both an elongation of taste cells and an increase in the width of the taste bud as the number of taste cells increases. It is evident in Figure 1 that mature taste buds (arrows) are both longer and wider at 45 days than at 10 days.

The most rapid increase in mature taste buds occurs from 5 to 30 days. Subsequently, mature taste buds are added at a decelerating rate until there is a maximum of $610 \pm 87$ mature taste buds per papilla at 90 days (Fig. 2). After 90 days the taste bud population shows a nonsignificant decline to a mean of $576 \pm 98$ taste buds per papilla at 180 days. Throughout the $0-90$-day period the total number of mature vallate taste buds is rather evenly divided among the four trench walls (Table 1).

In view of the necessity of effective suckling by neonates, we paid close attention to the status of taste buds at birth. The positive $x$-intercept of the curve in Figure 2 suggests there were no mature taste buds at birth. But since the curve was drawn by eye to fit the data from birth to 180 day, a better test for the presence of mature taste buds at birth would be to mathematically fit a curve to data from the first few weeks of the neonatal period. Accordingly, we fitted several curves to the data from $0-45$ days to obtain the most precise estimate of the mean number of mature taste buds present in a population of newborn rats. The best-fitting least squares curve, closely similar to Figure 2, was a third-order polynomial with an $x$-intercept of 1.5 days $(r=+.997)$. That is, the typical rat younger than 36 hours has no mature vallate taste buds. Given individual variation, an occasional mature vallate taste bud was found at birth. Specifically, we observed in the vallate papilla of 12 individuals within 36 hours of birth, one rat with 3 mature vallate taste buds, three rats with 1 mature taste bud and eight rats with none. The percentage of neonates with no mature vallate taste buds at early ages was $71 \%$ at 0 days, $60 \%$ at 1 days, and $25 \%$ at 3 days.

The general lack of mature taste buds at birth led us to evaluate whether immature taste buds, i.e., those lacking a taste pore, might reasonably serve as an anatomical substrate for taste in 0-1-day-old rats. The epithelial cells of the vallate papilla in newborns have an

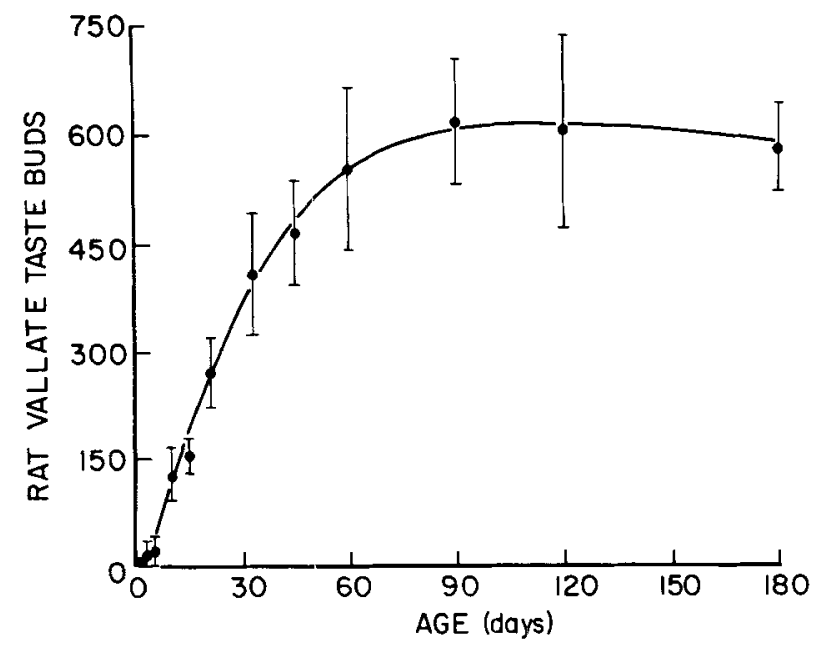

Fig. 2. The number of mature vallate taste buds in the rat (mean \pm 1 S.D.) is plotted as a function of age in days. A maximal mean of 610 \pm 87 vallate taste buds per papilla occurs at 90 days. Each data point represents the mean of 5-9 rats with a total $N$ of 84 rats. orderly alignment, except where they are disturbed by a mitotic event or by multicellular movements such as those that herald the appearance of taste buds. In order not to overlook possible immature taste buds, we counted any cluster of cells whose pattern of organization clearly disrupted the normal alignment of epithelial cells in the vallate papilla. By this definition we found means of 19.3 immature taste buds at birth and 17.7 in 1-day-old rat pups. As a rule, these immature taste buds were so small that they were not evident in more than one 10 . $\mu \mathrm{m}$ section. Immature taste buds were typically isolated from the trench by a substantial tissue barrier. Even the most developed of the immature taste buds at $0-1$ day had only a few cells and no visible access to the open trench (Fig. 3).

The depth of the trench and the length and width of the papilla all increase with age (Table 1). When length, width, and depth are plotted against $\log _{10}$ age, the Pearson correlation coefficients for the least-squares best-fit straight lines are +.92 (length) +.96 (width) and +.92 (trench depth). Since these variables are best estimated by the least-squares lines, the latter were used to calculate trench wall surface area (Table 1). Trench wall surface area was found to be a logarithmic function of age $(\mathbf{r}=+.99)$. Taste bud density, expressed as mature taste buds per square millimeter of trench wall surface area, rises significantly in the first postnatal month and then levels off by 6 weeks at 178 taste buds $/ \mathrm{mm}^{2}$ (Fig. 4). This ceiling on taste bud density is reached almost 2 months before all vallate taste buds have matured. For example, taste bud density reaches $90 \%$ of its maximum at 34 days (Fig. 4) when only $67 \%$ of mature vallate taste buds are present (Fig. 2).

Epidermal thickness, taste bud length, and taste bud width each increase to a maximum by 45 days (Table 1 ).

Figure 1 suggests that there may be an increase in the number of cells per taste bud between 10 and 45 days. To evaluate this quantitatively, we examined 20 24 taste buds in $6-\mu \mathrm{m}$-thick sections in the middle of the vallate papilla in each of three animals at $10,21,45$, and 90 days. We used the correction procedure of Abercrombie (1946) in determining the number of intragemmal cell nuclei per taste bud. We found that the number of cells at 10 days triples before reaching a maximum at 45 days. The most rapid addition of cells occurs between 10 and 21 days, when there is an average net addition of 3 cells/day (Table 1).

\section{DISCUSSION}

There have been no prior studies on the development of the rat vallate taste bud population, but Rehmer's (1969) data on the hamster suggested that the vallate taste bud population might require several months to reach a maximum. Our data document a prolonged postnatal accumulation of rat vallate taste buds. The first vallate taste buds mature 1.5 day after birth, and buds continue to increase in numbers to a maximum of $610 \pm 87$ taste buds per papilla at 90 days. The mean value of 610 vallate taste buds agrees with the mean of 611 reported by Oakley (1974). Guth (1957) counted 350400 vallate taste buds in female, Osborne-Mendell rats. However, he was examining the immature vallate papilla, as his rats weighed $100-150 \mathrm{gm}$, corresponding to an age of 38-42 days (Weisbroth, 1984). Hence, if one compares our data on comparably aged Sprague-Dawley 

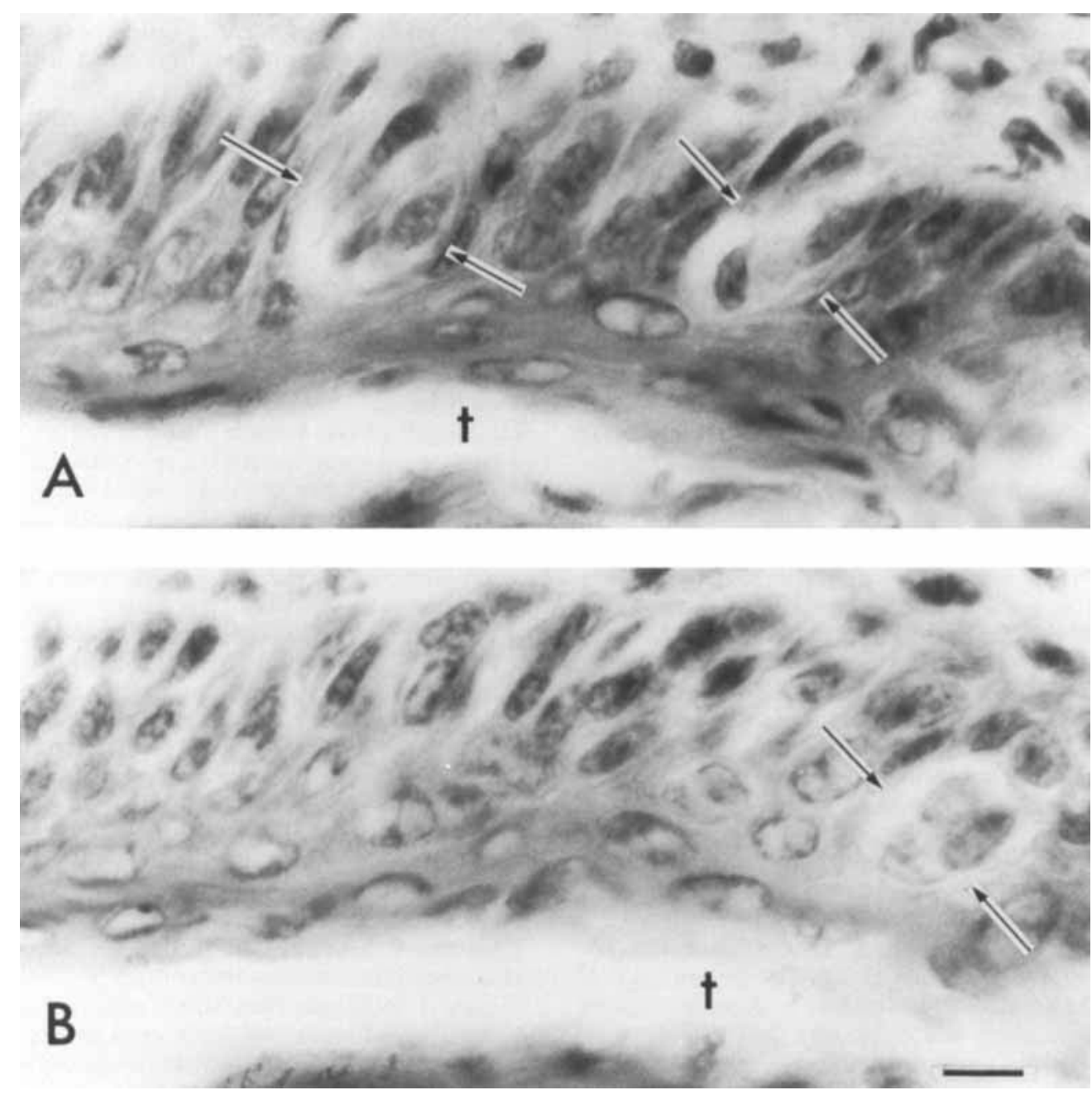

Fig. 3. Arrows indicate three of the most developed immature vallate taste buds observed in two newborn rats (A and B). Neither animal had a mature taste bud, i.e., one with a pore. The trench $(\dagger)$ is remote from the immature buds. Scale line $=10 \mu \mathrm{m}$.

rats with Guth's data, corrected for histological shrinkage, there is reasonable agreement on several variables: taste bud number ( 404 vs. his 375 ), papilla width and depth $(671 \times 518 \mu \mathrm{m}$ vs. $502 \times 478 \mu \mathrm{m})$ and epidermal thickness (98 vs. $92 \mu \mathrm{m}$ ).

To quantify the postnatal increase in the number of cells per taste bud, it was necessary to count the number of taste cell nuclei $/ 6-\mu \mathrm{m}$ section. Ultrastructural studies have reported counts of vallate taste bud cells that are similar to ours (Kinnamon et al., 1985) or lower than those reported here (Farbman, 1980). Vallate taste buds present a sampling problem, as there is wide variation in taste bud volume (unpublished observations). We tended to examine the larger taste buds in the middle of the papilla. From a sample of 264 taste buds, we determined that the mean number of cells per mature taste bud triples between 10 and 45 days (Table 1 ).

The thickening of the gustatory epithelium represents a specific example of the developmental thickening of the oral epithelium. Individual mature taste buds span the full thickness of the epithelium at all ages. These observations are consistent with the data from Table 1, where the relationship between the average thickness of the epithelium and the average length of mature taste buds is described by a straight line with a slope close to $1.0(r=+.96$; slope $=1.2)$. This suggests that, as animals age, existing mature taste buds must lengthen to adjust to the increasing thickness of the trench wall epithelium. The width of mature taste buds also increases with age. Taste buds presumably lengthen by cellular elongation, whereas they widen, in part, by increasing the number of cells per taste bud (Table 1).

Developmental changes in taste responses mediated by fungiform and vallate taste buds have been revealed by electrophysiological analyses (Hill et al., 1982; Mistretta and Bradley, 1983a,b). It is interesting to consider some possible mechanisms for such functional changes in development and maturation in light of the present findings and of the turnover of cells in taste buds. On the basis of the 9-10-day cell cycle of taste receptor cells 


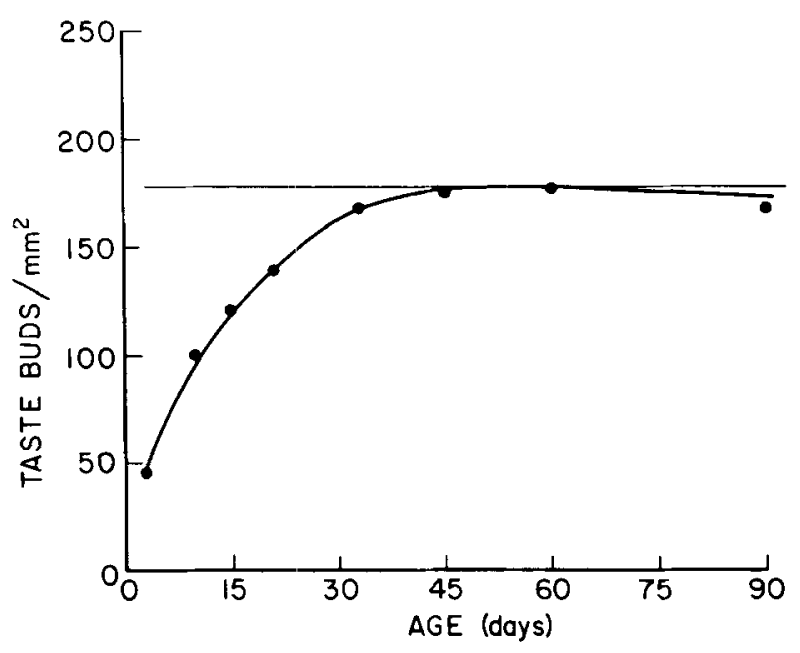

Fig. 4. The density of rat. vallate taste buds, expressed as the number of mature taste buds per square millimeter of trench wall epithelium, is shown as a function of postnatal age in days.

(Beidler and Smallman, 1965; Conger and Wells, 1969; Farbman, 1980), the 72-day interval between weak $\mathrm{NaCl}$ responses in the 110-day fetal sheep and the emergence of strong $\mathrm{NaCl}$ responses in the 35-day postnatal lamb would represent at least seven cell cycles during which the fetal taste receptor cells present at 110 days should have been repeatedly replaced. Thus, assuming young receptor cells turn over in a matter of days, the longterm functional changes in salt responses over a period of weeks (rat) or months (sheep) must reflect progressive changes across several cell generations and not the aging of short-lived individual cells. Stem cell differentiation across cell generations might explain changes in taste responses during development. Alternatively, on the basis of the present research, one must consider the possibility that the addition of more taste cells to the functional population may underlie developmental shifts in taste responses. Hence, if one focuses on receptor cells, developmental changes in taste nerve responses might occur if receptor cells are the differentiated daughters of stem cells that change over several cell generations, as more cells are added to existing taste buds or after the development of more taste buds.

Bradley et al. (1980) found a relatively stable taste bud density during growth of the lamb epiglottis. In the rat, we measured the length, width, and depth of the vallate papilla to calculate trench wall surface area and taste bud density. The density of mature taste buds reaches a ceiling almost 2 months before the number of mature taste buds stops increasing. Taste bud density is numerically constant after the first postnatal month because the area of the epidermis and the number of taste buds increase in parallel. Moreover, as the epidermis thickens during the first month, there is a concomitant increase in the length of the taste bud such that the basal surface of the taste bud remains adjacent to the basement membrane. At the same time, taste bud width also increases, which is attributable, in part, to an increase in the number of taste cells. Taste bud density, the length and width of taste buds, and the number of cells per mature taste bud all reach maxima between 33 and 45 days. Accordingly, taste bud maturation be- tween 45-90 days may be limited by the availability of space or by other density-dependent factors. For example, new taste buds might be added during the second and third postnatal months primarily where the continued extension of the trench provides additional gustatory epidermis. Elsewhere, a high packing density might preclude the formation of new taste buds and spatially constrain mature buds from adding more cells.

The early time course of proliferation of mature vallate taste buds (Fig. 2) and the analysis of individual animals indicates that few newborn rats have mature vallate taste buds. This supports Torrey's (1940) observations that albino rats lack vallate taste buds at birth. Our further studies indicate newborn rats also lack mature taste buds in the foliate papillae (Oakley and $\mathrm{Wu}$, unpublished). Rehmer (1969) found no vallate taste buds in 12 newborn hamsters. Smith and Miller (1986) report that the hamster has no mature taste buds in either the vallate or foliate papillae until 3-4 days after birth. Moreover, less than $2 \%$ of the fungiform taste buds had a pore in scanning electron micrographs of a newborn rat's tongue (Mistretta, 1972). Hence, the data from all five laboratories which have examined the development of taste bud populations in altricial rodents indicate that the tongue has few mature taste buds at birth. The electrophysiological responsiveness of taste nerves in newborn rats is unknown.

Suckling is the only mode of ingestion of newborn altrical mammals, such as rats and hamsters. It might seem that the virtual absence of lingual taste buds at birth would create difficulties in suckling and lead to high mortality. However, behavioral assays suggest that gustatory cues are of little importance in controlling fluid intake in newborn rats. Pups suckling an anesthetized dam show no preference for a lactating vs. a nonlactating nipple (Kenny et al., 1979). When the pup is attached to a nipple, the intra-oral delivery of water alone is sufficient to trigger the usual ingestive behaviors (Kehoe and Blass, 1985). At 3 days there is no significant increase in fluid intake with increasing sucrose concentration (Hall and Bryan, 1981). Three-dayold rat pups are not only unresponsive to quinine hydrochloride sufficiently strong to be invariably rejected by older rats $(0.0014 \mathrm{M})$, but their longer-term intake of quinine is not different from water until 9 days of age (Hall and Bryan, 1981).

In contrast, odor is significantly involved in the sensory control of suckling. Two-day-old rats can detect odors (Shapiro and Salas, 1970). Suckling in rat pups less than a week old is initiated by searching and attachment to the nipple. Removal of odors from the nipples by washing with solvent eliminates attachment to the nipple in 4-5-day-old rats (Teicher and Blass, 1976). In failing to attach to the deodorized nipple, $90 \%$ of the 4 5 -day-old rats never opened their mouths even when they were in contact with the nipple; that is, gustatory searching did not occur. Attachment to the nipple was reinstated after the washed nipples were treated with amniotic fluid or maternal saliva, but not after treatment with the saliva of virgin adult females (Teicher and Blass, 1977). Ablation of the olfactory bulbs eliminates suckling in neonatal rats (Singh and Tobach, 1974; Risser and Slotnick, 1985). Among the more specific olfactory pathways that may mediate suckling is the most histologically distinct glomerulus in the olfactory 
bulb of newborns, termed the modified glomerular complex. Its metabolic activity is greatly increased when newborn rats are presented with suckling odor cues (Greer et al., 1982).

Apparently, olfactory cues, and not gustatory cues, play the dominant role among the chemosensory stimuli driving suckling behavior. Taste may be involved in the ingestion of solid food. Lingual taste buds are well developed by the time ingestion of solid food is required, namely, at the time of weaning in altricial mammals or at birth in precocial mammals.

\section{SUMMARY AND CONCLUSIONS}

Lingual taste buds in the newborn rat, an altricial rodent, appear to be too immature to assist in suckling behavior. Vallate taste buds are added over a lengthy postnatal period leading to the development of $610 \mathrm{ma}$ ture taste buds by 90 days. Between 10 and 45 days postpartum, the population of mature taste buds undergoes a threefold increase in cells per taste bud, with cells added at net rates as high as three cells per day. The leveling out of the logarithmic increase in the trench wall surface area may be responsible for the upper limit of 70-75 cells per mature taste bud and for the maximal density of 178 taste buds $/ \mathrm{mm}^{2}$ of trench wall epithelium reached by 45 days. Developmental changes in the functional responses of taste neurons may reflect the contribution of newly added taste buds, the addition of more cells to existing buds, or gradual changes in receptor cell properties that endure beyond the lifespan of individual cells. Our data reveal a 3-month postnatal period of maturation when vallate taste buds form under dynamic morphogenetic control, ultimately involving the density-dependent addition of new taste buds.

\section{ACKNOWLEDGMENTS}

We are grateful for the support of B.L. Bower, D.J. Chiego, C.F. Cox, F.F. Ebner, S.E. Hughes, and L.L. Morton. Part of this research is based upon a dissertation submitted by M.A.H. in partial fulfillment of the doctoral degree requirements of the Rackham School of Graduate Studies at The University of Michigan. The research was funded in part by block grants from The University of Michigan Rackham School of Graduate Studies and by an NIH Javits Award (NS-07072).

\section{LITERATURE CITED}

Abercrombie, M. (1946) Estimation of nuclear population from microtome sections. Anat. Rec., 94:239-247.

Beidler, L.M., and R.L. Smallman (1965) Renewal of cells within taste buds. J. Cell Biol., 27:263-272.

Bradley, R.M. (1972) Development of taste bud and gustatory papillae in human fetuses. In: Third Symposium on Oral Sensation and Perception. J.F. Bosma, ed. Charles C. Thomas, Springfield, pp. 137-162.

Bradley, R.M., M.L. Cheal, and Y.H. Kim (1980) Quantitative analysis of developing epiglottal taste buds in sheep. J. Anat., 130:25-32.

Bradley, R.M., and I.B. Stern (1967) The development of the human taste bud during the foetal period. J. Anat., 101:743-752

Conger, A.D., and M.A. Wells (1969) Radiation and aging effects on taste structure and function. Radiat. Res., 37:31-49.

Farbman, A.I. (1965) Electron microscope study of the developing taste bud in rat fungiform papilla. Dev. Biol., 11:110-135.

Farbman, A.I. (1980) Renewal of taste bud cells in circumvallate papillae. Cell Tissue Kinet., 13:349-357.

Fish, H.S., D.D. Malone, and C.P. Richter (1944) The anatomy of the tongue of the domestic Norway rat. I. The skin of the tongue, the various papillae, their number and distribution. Anat. Rec., 89:429440 .

Geerdink, H.G. (1973) Some observations on the development of the vallate papilla of the mouse. Acta Morphol., 11:168.

Greer, C.A., W.B. Stewart, M.H. Teicher, and G.M. Shepherd (1982) Functional development of the olfactory bulb and a unique glomerular complex in the neonatal rat. J. Neurosci., 2:1744-1759.

Guth, L. (1957) The effects of glossopharyngeal nerve transection on the circumvallate papilla of the rat. Anat. Rec., 128:715-731.

Guth, L. (1963) Histological changes following partial denervation of the circumvallate papilla of the rat. Exp. Neurol., 8:336-349.

Hall, W.G., and T.E. Bryan (1981) The ontogeny of feeding in rats: IV. Taste development as measured by intake and behavioral responses to oral infusions of sucrose and quinine. J. Comp. Physiol. Psychol., 95:240-251.

Hill, D.L., C.M. Mistretta, and R.M. Bradley (1982) Developmental changes in taste response characteristics of rat single chorda tympani fíbers. J. Neurosci., 2:782-790.

Humanson, G.L. (1979) Animal Tissue Techniques, 4th ed. W.H. Freeman, San Francisco, $661 \mathrm{pp}$.

Kehoe, P., and E.M. Blass (1985) Gustatory determinants of suckling in albino rats 5-20 days of age. Dev. Psychobiol., 18:67-82.

Kenny, J.T., M.L. Stoloff, J.P. Bruno, and E.M. Blass (1979) Ontogeny of preference for nutritive over nonnutritive suckling in albino rats. J. Comp. Physiol. Psychol., 93:752-759.

Kinnamon, J.C. B.J. Taylor, R.J. Delay, and S.D. Roper (1985) Ultrastructure of mouse vallate taste buds. I. Taste cells and their associated synapses. J. Comp. Neurol., 235:48-60.

Mistretta, C.M. (1972) Topographical and histological study of the developing rat tongue, palate and taste buds. In: Third Symposium on Oral Sensation and Perception. J.F. Bosma, ed. Charles C. Thomas, Springfield, pp. 163-187.

Mistretta, C.M., and R.M. Bradley (1983a) Developmental changes in taste responses from glossopharyngeal nerve in sheep and comparisons with chorda tympani responses. Dev. Brain Res., 11:107-117.

Mistretta, C.M., and R.M. Bradley (1983b) Neural basis of developing salt taste sensation: Response changes in fetal, postnatal and adult sheep. J. Comp. Neurol., 215:199-210.

Oakley, B. (1974) On the specification of taste neurons in the rat tongue. Brain Res., 75:85-96.

Rehmer, H. (1969) Die Entwicklung der Papilla vallata und der Anzahl ihrer Geschmacksknospen beim Goldhamster (Mesocricetus auratus Waterhouse, 1839). Anat. Anz., 125:274-288.

Risser, J.M., and B.M. Slotnick (1985) Complete but not partial olfactory bulbectomies block suckling behavior in neonatal rats (abstr.). Chem. Senses 10:410.

Shapiro, S., and M. Salas (1970) Behavioral responses of infant rats to maternal odor. Physiol. Behav., 5:815-817.

Singh, P.J., and E. Tobach (1974) Olfactory bulbectomy and nursing behavior in rat pups (Wister DAB). Dev. Psychobiol. 8:151-164.

Smith, D.V., and I.J. Miller, Jr. (1986) Taste bud development in hamster vallate and foliate papillae (abstr.). Chem. Senses, 11:665.

Teicher, M.H., and E.M. Blass (1976) Suckling in newborn rats: Eliminated by nipple lavage, reinstated by pup saliva. Science, 193:422425.

Teicher, M.H., and E.M. Blass (1977) First suckling response of the newborn albino rat: The roles of olfaction and amniotic fluid. Science 198:635-636.

Torrey, T.W. (1940) The influence of nerve fibers upon taste buds during embryonic development. Proc. Natl. Acad. Sci. USA, 26:627-634.

Weisbroth, S.H. (1984) Diagnostic Report on CAMM Research Lab Animals, Osborne-Mendell Rats. Ann Med Lab, Inc., New Hyde Park, N.Y.

Whiteside, B. (1927) Nerve overlap in the gustatory apparatus of the rat. J. Comp. Neurol., 44:363-377.

Zahm, D.S., and B.L. Munger (1983) Fetal development of primate chemosensory corpuscles. II. Synaptic relationships in early gestation. J. Comp. Neurol., 219:36-50. 